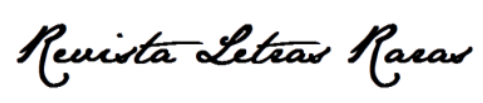

ISSN: 2317-2347 - v. 9. n. 1 (2020)

Todo o conteúdo da RLR está licenciado sob Creative Commons Atribuição 4.0 Internacional

\title{
Para um ensino/aprendizagem de gramática contrastiva em departamentos de língua estrangeira: o exemplo do demonstrativo em francês e em polonês ${ }^{1}$ / Teaching and learning contrastive grammar in Foreign Language Departments: the example of French and Polish demonstratives
}

\author{
Joanna Górnikiewicz * \\ Universidade Jagellonne de Cracovie, Polônia. \\ iD https://orcid.org/0000-0001-9375-4896
}

Recebido em 10 out. 2019. Aprovado em: 15 nov. 2019.

\section{Como citar este artigo:}

GÓRNIKIEWICZ, Joanna. Para um ensino/aprendizagem de gramática contrastiva em departamentos de língua estrangeira: o exemplo do demonstrativo em francês e em polonês. Revista Letras Raras, [S.I.], v. 9, n. 1, 2020. p. Port. 168-183 / Eng. 165-181. ISSN 2317-2347, UFCG: Campina Grande, 2020.

\section{RESUMO}

Neste artigo, com base numa classe de palavras escolhida, a autora compartilha sua experiência como professorapesquisadora encarregada das aulas de gramática contrastiva franco-polonesa, em um departamento de língua estrangeira de uma universidade polonesa. Tendo em conta a utilidade do assunto para a matéria, ela questiona 0 conteúdo e as referências bibliográficas a serem propostas. A autora mostra que, embora as duas línguas tenham formas comparáveis, a utilização que é feita delas não é necessariamente idêntica, assunto que as obras comparativas disponíveis não apresentam.

PALAVRAS-CHAVE: gramática contrastiva, cursos universitários, aprendiz, professor, classe dos demonstrativos

\section{RÉSUMÉ}

Dans cet article, à partir d'une classe de mots choisie, l'auteur partage son expérience d'enseignant-chercheur chargé de cours de grammaire contrastive polono-française dans un département de langues étrangères d'une université polonaise. Tenant l'utilité de la matière pour acquise, elle s'interroge sur le contenu et les références bibliographiques à proposer. Elle montre que même si les deux langues disposent de formes comparables, l'usage qui en est fait n'est pas forcément identique, ce que les ouvrages comparatifs disponibles ne mettent pas en avant. MOTS-CLÉS : grammaire contrastive, cursus universitaire, apprenant, enseignant, classe de démonstratifs

\section{ABSTRACT}

In this article, the author, a lecturer and researcher in the Department of Foreign Languages at one Polish university, shares her teaching experience in contrastive French-Polish grammar. Having taken the utility of the subject for granted, she wonders about the appropriate program and bibliographic references. Using the example of one word class, the author shows that even where two languages have the same categories, there can be variation in terms of how they are used by speakers. This question is not emphasized enough in the available contrastive grammars.

KEYWORDS : contrastive grammar, university course, student, teacher, demonstratives

\footnotetext{
1 Pour un enseignement/apprentissage de la grammaire contrastive dans les départements de langues étrangères : l'exemple du démonstratif en français et en polonais. Traduzido por Ana Beatriz Aquino da Silva e João Leonel de Farias Silva e revisado por Nyeberth Emanuel Pereira dos Santos. Publicado em Synergies pays riverains de la Baltique $\mathrm{n}^{\circ} 12$ - 2018 p. 11-24. In : https://gerflint.fr/Base/Baltique12/gornikiewicz.pdf
}

\joanna.gornikiewicz@uj.edu.pl 




ISSN: 2317-2347 - V. 9, n. 1 (2020)

Todo o conteúdo da RLR está licenciado sob Creative Commons Atribuição 4.0 Internacional

\section{Introdução}

Definida pelos trabalhos linguísticos, de modo geral, como a descrição das diferenças e das semelhanças entre, pelo menos, duas línguas (KOCZERHAN, 2009), a gramática contrastiva (aplicada) é vista tanto como uma chance para os alunos e os professores (NEMSER, 1975), quanto é vista como um obstáculo na aquisição e no ensino de uma língua estrangeira (KRÓLMARKEFKA, 2008). Mas, qual papel Ihe atribuir nos departamentos de línguas estrangeiras onde o professor tem, diante dele, um público bastante particular? Inicialmente, simples aprendizes, os estudantes são formados para se tornarem professores ou usuários particulares de línguas estrangeiras, a exemplo dos tradutores e intérpretes. Uma gramática contrastiva, para sê-los útil, deveria elucidar os contrastes dos aspectos estruturais e funcionais entre as duas línguas, a fim de permitir eliminar e de excluir eventuais interferências. No entanto, deve-se levar em consideração o aspecto pragmático-linguístico (JAZOWY-JARMUŁ, 2014) e 0 textual, com 0 objetivo final de produzir enunciados não só gramaticalmente corretos, mas percebidos também como naturais em uma língua estrangeira (WÓJCIK, 1974).

As diferenças que aparecem entre o polonês e o francês, assim como aquelas que se apresentam entre os sistemas descritivos correspondentes foram, até agora, objeto de algumas publicações. No entanto, elas são, principalmente, artigos ou livros científicos, destinados a especialistas e, portanto, pouco conhecidas por um público mais amplo. Esses trabalhos tratam, geralmente, de algum problema detalhado, enquanto as gramáticas que apresentam uma descrição global das duas línguas permanecem relativamente em menor número. Em nossa contribuição, baseada no exemplo de uma classe de palavras escolhida, tentaremos responder às seguintes questões: essas obras, de uso geral, podem ser usadas como livros didáticos para aprendizagem/ensino do FLE, no meio universitário? Elas devem servir como livros de referência para o curso de gramática contrastiva? E, no caso de uma resposta negativa, como organizar 0 curso (que conteúdo e quais referências escolher) para que os alunos obtenham um êxito maior e não caiam em novas armadilhas?

\section{Obras disponíveis}

O primeiro livro com viés comparativo surgiu na Polônia no final dos anos de 1950, na coleção da Sociedade Científica de Lodz. Trata-se da Estrutura das Línguas Francesa e 


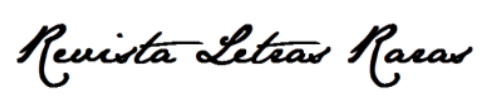

ISSN: 2317-2347 - v. 9, n. 1 (2020)

Todo o conteúdo da RLR está licenciado sob Creative Commons Atribuição 4.0 Internacional

Polonesa de Bolesław Kielski, composta de duas partes $(1957,1960)$ finalizada com o Dicionário de terminologia gramatical francesa e polonesa (1959). Os três volumes foram escritos em polonês. A obra Estrutura não é considerada por seu autor como uma gramática. Encontramos um relato sobre isso no Prefácio do Dicionário: "não há gramática contrastiva franco-polonesa, e é duvidoso se tal projeto deve emergir (comparar a estrutura das línguas é uma coisa diferente)" (KIELSKI, 1957, p. 7, tradução nossa²). Assim, o mérito de ser o primeiro autor deste tipo de publicação é de Stanisław Gniadek, um dos relatores do Dicionário de Kielski. Sua gramática contrastiva franco-polonesa, escrita em francês e editada pela editora nacional PWN, provavelmente seria útil para estudantes de filologia românica, na Polônia, e aos slavistas franceses (GNIADEK, 1979, p. 7). O trabalho mais recente deve-se a Katarzyna KwapiszOsadnik que, em 2007, publicou em polonês um esboço comparativo intitulado Podstawowe wiadomości z gramatyki polskiej i francuskiej (Livro de gramatica polonesa e francesa). 0 público-alvo é mais amplo (KWAPISZ OSADNIK, 2007, p.7) e até excede o do Dicionário de Kielski (1959, p. 5), que não é dirigido aos filólogos romanos. Por outro lado, o objetivo é mais modesto:

A forma do livro parece mais como uma justaposição de noções gramaticais do que um vasto estudo comparativo. A questão é apontar as semelhanças e diferenças nas terminologias polonesa e francesa, e não estudar profundamente ou descrever os fenômenos linguísticos. (KWAPISZOSADNIK, 2007, p. 8, nossa tradução).

\section{Um exemplo: o demonstrativo}

Para apoiar nosso ponto de vista, escolhemos uma classe de palavras cuja frequência de ocorrência e diversidade de empregos em uma obra literária nos levou a examinar mais atentamente os livros didáticos existentes, bem como as possíveis necessidades e expectativas do público sobre o conteúdo dos livros disponíveis e do ensino proposto. Trata-se da classe dos demonstrativos, mais particularmente dos determinantes demonstrativos, muito presentes no texto de Courrier Sud de Antoine de Saint-Exupéry.

Estes demonstrativos e as formas comparáveis em polonês são, em nossa opinião, interessantes em três aspectos:

\footnotetext{
2 As traduções do polonês para o francês foram realizadas pela autora do texto, a exemplo desta.
} 


\section{Penista Leteas Paras}

ISSN: 2317-2347 - v. 9, n. 1 (2020)

Todo o conteúdo da RLR está licenciado sob Creative Commons Atribuição 4.0 Internacional

- a nível de sistema, devido a: a) sua forma, b) sua natureza e sua função sintática [agentes que transmitem uma indicação adicional (GREVISSE-GOOSSE, 2016) para oS franceses versus elementos de caracterização para o polonês];

- a nível pragmático e textual, por causa de sua eventual (ou não) correspondência.

Os demonstrativos franceses encontram seu lugar na classe dos determinantes (ou nos adjetivos determinantes ou não-qualificativos, segundo as terminologias) - para a série de ce (ce livre) -, ou na dos pronomes - para a série de celui (celui que j'ai lu). Para estas formas distintas, o polonês opõe a uma única série: os demonstrativos "que servem tanto para o uso adjetivo como para o uso pronominal" (GNIADEK 1979, p. 81). Esta série é classificada nas gramáticas polonesas tradicionais sob o rótulo de "pronome adjetival", pl. zaimek przymiotny. Trata-se, ates de tudo, das formas que marcam as diferenças de distância no espaço ou tempo ten vs tamten (formas próximas e distantes de acordo com Kielski (1959, p. 17, 63-64), variáveis em número e gênero (o polonês tendo três gêneros). Essas formas são complementadas pela variante literária ów (anafórica) e o pronome adjetivo taki, formando um segundo subsistema usado em mecanismos referenciais de reconhecimento (PAPIERZ, 2003, p. 72) (que não serão analisados aqui). Deve-se notar, no entanto, que a forma simples pode denotar, tanto isoladamente quanto em um grupo nominal, tanto os objetos próximos quanto os objetos distantes do locutor, enquanto formas morfologicamente complexas (tam [lá] + ten) só podem se referir a objetos distante. Quanto ao francês, ele possui um sistema assimétrico, no qual as formas simples, em princípio neutras no que diz respeito à distinção entre proximidade e distância, e as formas compostas por ce N-ci/lá, são muito menos frequentes, onde essa distinção é explicitamente marcada (JONASSON, 2002, p. 111). As formas com a partícula là se opõem, hoje, à forma simples que marca, na prática, a proximidade, enquanto a forma com ci se utiliza quando há, realmente, um contraste que precisa ser marcado (JONASSON, 2002, p. 111).

Assim, encontramos as formas que nos interessam divididas em diferentes classes e apenas Kielski (1959: 114, 117-118) adverte o leitor contra uma possível confusão, especificando no verbete de entrada Pronome, de seu Dicionário, que o termo francês tem uma extensão mais restrita (os pronomes substituem um nome ${ }^{2}$ ) do que o do zaimek. De fato, os pronomes poloneses são divididos em quatro subclasses, conforme o papel que eles desempenham, seja um nome, um adjetivo, um numeral ou um advérbio. No entanto, nenhum dos autores indica os critérios que estão na origem das diferenças terminológicas entre a gramática francesa e a 


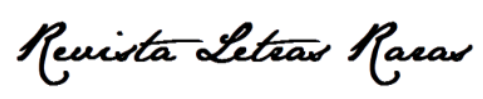

ISSN: 2317-2347 - v. 9, n. 1 (2020)

Todo o conteúdo da RLR está licenciado sob Creative Commons Atribuição 4.0 Internacional

gramática tradicional polonesa ${ }^{3}$. E essas diferenças continuam a desafiar os leitores de línguas francófonas e polófonas.

\section{Usos dos demonstrativos de acordo com as gramáticas}

\subsection{Le tertium comparationis: as três comparações}

Vamos agora nos voltar para o que as gramáticas abordam, geralmente pouco ou que nem chegam a abordar: para os usos de demonstrativos em ambas as línguas, em outras palavras, para seu valor semântico e textual. Por um lado, estes são os aspectos mais interessantes (PAPIERZ, 2003, p. 13), por outro lado, sua consideração permitirá criar uma análise comparativa completa (KOCZERHAN, 2009, p. 17). Para fazer isso, é necessário, pelo menos em parte, desistir da tentação de conceder um status privilegiado a uma das línguas confrontadas e recorrer a noções consideradas universais, um princípio imutável que deve estar na origem de cada gramática contrastiva. Assim, a noção de referência (PADUČEVA, 1992, p. 15) será levada em consideração, assim como a noção de dêixis e do caráter definido/indefinido do referente (PAPIERZ, 2003, p. 12, 16). No que diz respeito a esta última categoria, entretanto, o caráter indefinido de um elemento deve ser entendido de maneira diferente em uma língua privada de marcas explícitas de tal oposição (artigos ou outras marcas morfológicas para tais propósitos) (PISARKOWA, 1969, p. 47).

\subsection{A instrução referencial}

De acordo com as definições tradicionais, o demonstrativo, como o próprio nome sugere, deveria "mostrar um objeto" (DUBOIS et al., 1999). Na Polônia, os critérios semânticos ainda estão firmemente enraizados na gramática escolar (SYNOWIEC, 2001, p. 98), herdeira da gramática tradicional, para a qual o critério da demonstração é definitivo para toda a classe de pronomes (SZOBER, 1969, p. 19-18; LASKOWSKI, 1999, p. 53) ou permite mais especificamente definir o demonstrativo (JODŁOWSKI, 1973, p. 47). Nas duas línguas, também reconhecemos igualmente a oposição de dois tipos de emprego: dêitico e anafórico, assim chamado in praesentia, sejam estes nos quais, de acordo com a metáfora de Bühler, o receptor é guiado "no reino do que está presente", na situação de enunciação ou no contexto textual. 


\section{Penista Leteas Paras}

ISSN: 2317-2347 - v. 9, n. 1 (2020)

Todo o conteúdo da RLR está licenciado sob Creative Commons Atribuição 4.0 Internacional

Atualmente, a insuficiência das definições e distribuições tradicionais não precisa mais ser demonstrada. Segundo os pesquisadores franceses, dos quais faremos uso do ponto de vista, o papel privilegiado deve ser dado ao contexto da enunciação, necessário para a identificação do referente da expressão demonstrativa (por exemplo, KLEIBER, 1983, 1990; CORBLIN, 1987; DE MULDER, 1998; GARY-PRIEUR; LEONARD, 1998). O demonstrativo é qualificado como um designador direto (KLEIBER, 1990), semanticamente incompleto, invariavelmente trazendo novidade através da contextualização. Como tal, seu caráter seria puramente dêitico (DE MULDER, 1998, p. 21) e a única questão que surge é a de saber que tipo de dêixis ele é (KLEIBER, 2003, p. 37). Numa perspectiva comparativa, teremos que saber se as línguas analisadas usam os demonstrativos da mesma maneira.

\subsection{Os usos do demonstrativo polonês (adjetivo) identificados nas gramáticas contrastivas.}

Em polonês, o nome não precisa ser precedido por um determinante a ser atualizado. É insinuado, como aponta Gniadek (1979, p. 73), "o artigo não existe e a predeterminação, quando necessária, é alcançada pelo uso de adjetivos pronominais". No entanto, em sua Gramática, a única observação sobre o uso de demonstrativos em polonês diz respeito ao seu uso ocasional, como equivalentes do artigo definido "que por vezes tem o significado do demonstrativo, ex. de la sorte - w ten sposób"(p. 76). Esses empregos, qualificados por Pisarkowa (1969, p. 56) como fraseológicos, constituem o único contexto que implica a presença do demonstrativo em polonês ${ }^{4}$. Kwapisz-Osadnik (2007, p. 40), por sua vez, afirma que, mesmo que o polonês não tenha artigos, seu papel, às vezes, é preenchido pelo demonstrativo, por exemplo Podaj mi ten nóż - Donne-moi le couteau! (Veja também KIELSKI, 1960, p.52). Quanto a Kielski, ele foi o único a incluir e a apoiar, com exemplos concretos, observações específicas sobre o papel desempenhado pelo demonstrativo polonês:

Lá, onde o francês generaliza por meio do uso do artigo indefinido, o idioma polonês, embora de maneira esporádica, admite o uso de um pronome demonstrativo (adjetivo), p. ex. : 'Pracuje jak ten wól, 'Któż to sprawił jak nie ci huligani?' (KIELSKI, 1960, p. 54).

As formas pronominais ten, ci, estão aqui "funcionalmente enfraquecidas e privadas de acento" e constituem o equivalente do artigo definido. $O$ valor semântico também é neutralizado nas estruturas exclamativas do tipo: 'Oj ta zima!', 'Ach ten dziwak!' (Eh, cet hiver! Ah! cet original!), ou onde, em francês, aparece frequentemente um determinante exclamativo (KIELSKI, 


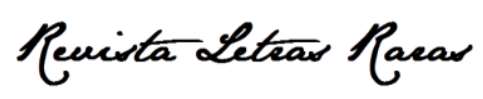

ISSN: 2317-2347 - v. 9, n. 1 (2020)

Todo o conteúdo da RLR está licenciado sob Creative Commons Atribuição 4.0 Internacional

1960, p. 55), sem, no entanto, o demonstrativo ser excluído, por exemplo Cette folle! (MARIVAUX) (RIEGEL et al., 2016, p. 691).

\section{0 valor referencial dos demonstrativos}

Mas, e sobre os empregos reconhecidos nas duas línguas? Eles se correspondem? As gramáticas contrastivas ignoram este problema, o que questiona sua utilidade na aprendizagem/ensino do FLE e o restringe consideravelmente, mesmo em aulas de gramática contrastiva. No entanto, alguns exemplos são suficientes para mostrar que os falantes de ambos os idiomas nem sempre exploram, da mesma maneira, as formas colocadas à disposição deles.

Em nosso estudo, que tenta preencher parcialmente as lacunas existentes na literatura contrastiva, vamos nos referir à dêixis de Bühler ( 2009). Vamos nos concentrar na referência estabelecida no eixo Texto - Realidade, deixando de lado, por falta de espaço, o outro componente dos empregos in praesentia (dêixis derivada), ou seja, a referência estabelecida no eixo Texto - Texto. Por outro lado, levaremos em consideração os empregos nos casos em que a busca do referente não pode ser feita fora da expressão em si, os chamados empregos in absentia, ou seja, aqueles que correspondem à dêixis am Phantasma (o segundo dos modos de indicação derivados). Sendo assim, nossa atenção estará voltada para as descrições incompletas correlacionadas ou não com um gesto, mas invariavelmente acompanhadas por seu correlato linguístico, tanto no modo dêitico padrão quanto na referência dêitica imaginária (TOPOLIŃSKA, 1984, p. 312).

\subsection{Empregos in praesentia ou o modo dêitico padrão}

\section{a) Empregos realizados ostensivamente}

O demonstrativo é ou pode ser acompanhado por um índice adicional: "dedo esticado, movimento da cabeça ou um simples olhar" (Kleiber, 1983, p. 104) que se refere a objetos designáveis por ostensão no espaço enunciativo. Por exemplo, esta conversa entre dois pilotos, em que o mais experiente diz ao novato em um mapa como sobrevoar a Espanha com segurança: 


\section{Penista Letras Paras}

ISSN: 2317-2347 - v. 9, n. 1 (2020)

Todo o conteúdo da RLR está licenciado sob Creative Commons Atribuição 4.0 Internacional

- Écoute-moi donc : s'il fait beau, tu passes tout droit. Mais s'il fait mauvais, si tu voles bas, tu appuies à gauche, tu t'engages dans cette vallée. (CS, p. $8)^{3}$

- Słuchaj więc : jeśli będzie ładnie lecisz prosto przed siebie. Ale jeśli pogoda się zepsuje, jeśli będziesz leciał nisko, bierzesz kurs na lewo, na tę dolinę. (PP, p. 37)

Segundo Topolińska (1984, p. 312), a presença do correlato linguístico do gesto - do demonstrativo ten - é obrigatória em polonês nos enunciados em que a predicação incide sobre a identidade do referente, de modo que a oposição não é necessariamente explícita. Quanto ao gesto em si, é indispensável onde um ser ou vários objetos devem ser identificados entre muitos outros (e em um mapa, há muitos vales que sulcam o terreno montanhoso); é, no máximo, opcional quando o problema de reconhecimento de referência não surge. Então em:

- Qui a goupillé ce capot?

- Moi. $(C S, \text { p. } 5)^{5}$

como acabamos de discutir os preparativos para a decolagem de um avião de correspondência, o líder da pista que "gira em torno das manobras" não precisa unir o gesto à palavra, para que eles saibam qual objeto que ele visa. Segundo Topolińska (1981, p. 42), em polonês, numa situação em que o grupo nominal se refere a um objeto facilmente identificável pelo interlocutor, o uso do demonstrativo é justificado; entretanto, não se pode dizer que seu uso seja sistemático. E a tradução polonesa dessa passagem corrobora nosso propósito:

- Kto zamocowywał nakrywę silnika?

- Ja. $(P P$, p. 32) 6

Em polonês, língua "sem determinantes" (sem atualizadores), a informação sobre a referência é dada pela estrutura semântica da sentença. Assim, em nosso exemplo, a tradutora, para facilitar a referência do repositório ao leitor (as manobras não precisariam dessa referência), acrescentou uma precisão na forma de complemento do nome: nakrywa silnika (tampa do motor).

\footnotetext{
3 - Ouça-me então: se o tempo estiver bom, você vai direto. Mas se estiver ruim, se você voar baixo, você pressiona à esquerda, entra nesse vale. (CS, p. 8)

4 - Então escute: se você voar bem, siga em frente. Mas se o tempo desmoronar, se você estiver voando baixo, siga o curso para a esquerda, para este vale. (PP, p. 37)

5 - Quem fixou esse capô?

- Eu. (SC, p.5)

6 - Quem montou a tampa do motor?

- Eu. (PP, p. 32)
} 


\section{Peuista Leteas Parar}

ISSN: 2317-2347 - v. 9, n. 1 (2020)

Todo o conteúdo da RLR está licenciado sob Creative Commons Atribuição 4.0 Internacional

\section{b) Trabalhos realizados sem gestos}

O demonstrativo também pode denotar referentes não materiais sobre os quais não podemos apontar. Esse é, particularmente, o caso das expressões temporais. Em francês, os demonstrativos são usados para gravar enunciados no tempo, em relação ao presente do falante. Similarmente, em polonês, ten aparece frequentemente em grupos sintáticos funcionando como complementos de tempo e "demonstra/mostra a distância mais curta" (PISARKOWA, 1969, p. 57). No entanto, os falantes das duas línguas analisadas não exploram as possibilidades sistêmicas da mesma maneira. Se em francês (do Hexágono), "quando chega o dia em que estamos, usamos ce matin e ce soir" (Grevisse-Goosse, 2016: 1045 c) $1^{\circ}$ ), em polonês o advérbio dêitico 'hoje' (dziś, dzisiaj) é o único apropriado7, como neste conselho dado a Geneviève pelo médico de seu filho:

Vous vous fatiguez trop. Ce n'est pas sérieux. Je vous donne l'ordre de sortir cet aprèsmidi. (CS, p. 27)

Pani jest przemęczona. To nic poważnego. Polecam pani wyjść dziś po południu z domu. $\left(P P\right.$, p. 32) ${ }^{7}$

\section{c) Empregos realizados indiretamente}

É a referência demonstrativa, não gestual, a um objeto não presente, que pode ser identificado a partir dos elementos do contexto de enunciação, em relação à ocorrência da descrição demonstrativa (Kleiber, 1990: 160). Assim, no exemplo abaixo, sem introdução ou presença efetiva do referente, o líder de pista esperando pela entrega diária pode muito bem dizer, tanto em francês como em polonês:

Ce pilote a toujours du retard.

Ten pilot ciaggle się spóźnia. 8

Se ele pode fazê-lo, é porque o referente é identificável a partir do contexto da enunciação - 0 lugar onde a sentença é pronunciada (o aeroporto) e o momento da enunciação que pode: a) coincidir com a chegada prevista da aeronave (surpresa); b) ser anterior a ele (argumento a favor de 'ainda há tempo') ou c) posterior (impaciência, irritação).

\footnotetext{
7 Você está cansado demais. Não é sério. Eu te dou a ordem para sair esta tarde. (SC, 27)

Você está sobrecarregado. Não é nada sério. Eu recomendo que você saia desta casa esta tarde. (PP, p. 32)

8 Esse piloto está sempre atrasado.

Este piloto ainda está atrasado.
} 


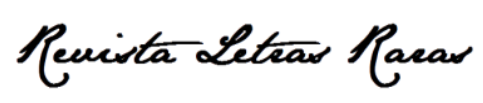

ISSN: 2317-2347 - v. 9 , n. 1 (2020)

Todo o conteúdo da RLR está licenciado sob Creative Commons Atribuição 4.0 Internacional

\subsection{Os empregos in absentia ou a referência dêitica imaginária}

A partir desta denominação, encontra-se, na literatura, diferentes trabalhos onde a busca pelo referente não pode ser feita fora da própria expressão. 0 centro dêitico responsável pela apreensão demonstrativa e indicador do ponto de vista (Kleiber, 2003, p. 41) se vê deslocado, 0 falante não pode mais assumir esse papel. A dêixis am Phantasma é "uma dêixis cuja pontuação é feita em espaços ou áreas mentais" e torna possível o movimento em dois reinos: o reino imaginário e o memorial (Bühler, 2009; Kleiber, 2003, p. 39). Os exemplos abaixo estão todos dentro do domínio da memória. Embora ele ainda seja vasto demais para explorar, nós privilegiamos a referência particular solicitando a memória de "tu".

Em ambas as línguas, o demonstrativo aparece em contextos nos quais o falante e 0 receptor compartilham conhecimento comum sobre uma situação ou têm uma experiência comum (TOPOLINSKA, 1981, P. 45), (KLEIBER, 2003, p. 44). Então em:

- $\quad$ Ah la Grèce, cette mer, ces îles ! (Wilmet, 1986, apud Kleiber, 2003, p.35)

- Ależ ten wczorajszy gość był nudny. (TOPOLIŃSKA, 1981, p. 46) 9

refere-se a uma viagem que foi feita juntos ou separadamente, mas no mesmo lugar, a uma noite passada juntos ou da qual foi informada previamente ao nosso interlocutor. A isto se somam as mensagens pertencentes à terminologia de Topolińska (1981, p. 46) à série "te souviens-tu?":

Ah te souviens-tu de ce prof de maths qui mettait des bonnes notes à toutes les copies ? (KLEIBER, $2003:$ 44)

Czy pamiętasz tego chłopca w czerwonej czapeczce, który się bawił wczoraj przed domem ? (TOPOLIŃSKA, 1981: 46) 10 bem como referências a informações lidas ou ouvidas na mídia, sobre as quais se supõem um conhecimento por um público amplo, (TOPOLIŃSKA, 1981, p. 46) ou a situações de rumores que ocorrem em ambiente fechado:

Avez-vous entendu parler de cette île bretonne 100\% autosuffisante en énergie ? (Página do Facebook de Mr Mondialisation, le 9 octobre 2017)

\footnotetext{
${ }^{9}$ Ah, a Grécia, esse mar, essas ilhas! (WILMET, 1986, apud KLEIBER, 2003: 35) Mas o convidado de ontem foi chato. (TOPOLIŃSKA, 198, p. 46)

${ }^{10} \mathrm{Ah}$, lembra-se daquela professora de matemática que colocou boas notas em todas as cópias? (KLEIBER, 2003, p. 44) Você se lembra daquele garoto de boné vermelho que estava jogando fora de casa ontem? (TOPOLIŃSKA, 1981, p. 46).
} 


\section{Penista Leteas Paras}

ISSN: 2317-2347 - v. 9, n. 1 (2020)

Todo o conteúdo da RLR está licenciado sob Creative Commons Atribuição 4.0 Internacional

Słyszałeś o tym nowym podinspektorze ? podobno ma przyjść do nas na szefa wydziału. (Zajas, Z otchłani, 2015) ${ }^{11}$

Como Kleiber (2003, p. 44) aponta, "é apenas no caso do demonstrativo que se tem a impressão de uma visão ou percepção direta ou, pelo menos, de uma experimentação direta da entidade denotada". Ele ressalta que "é a 'percepção' ou experiência do falante no passado que se encontra reativada". Com o definido (ou sem determinante em polonês), não haveria mudança de ponto de vista e o passado seria alcançado a partir da situação de enunciação. No Courrier Sud, esse emprego não é marginal:

Te souviens-tu de ce premier départ ? Nous l'avons fait ensemble [...] Le moteur faisait ce bruit dense qui existe seul et derrière lequel le paysage passe en silence comme un film. Et ce froid, car nous volions haut : ces villes prises dans la glace. (CS, p. 18)

Czy pamiętasz nasz pierwszy wyjazd ? Byliśmy wtedy razem [...] Zdawało się nie istnieć nic poza gęstym szumem silnika, a pod nim krajobraz przesuwał się bezgłośnie jak film. I ten chłód - bo lecieliśmy wysoko: miasta zakrzepłe w lodzie. $(P P, \text { p. 32 })^{12}$

Essa passagem refere-se explicitamente à memória comum de Bernis, autor da carta, e do piloto-narrador anônimo, seu duplo (ODAERT, 2009), que é o destinatário. Dos quatro demonstrativos franceses, o tradutor polonês manteve apenas um e ele não estava errado. Seria estilisticamente insustentável torná-los todos correspondentes em polonês (apenas por causa das peculiaridades tipológicas desta língua) e, ainda assim, a referência de memória não desapareceu completamente. 0 primeiro demonstrativo, aquele cuja interpretação foi facilitada pelo cotexto subsequente, foi substituído pelo possessivo inclusivo nasz, que mostra explicitamente que o objeto denotado deve ser percebido a partir de uma situação passada, constituindo a experiência comum dos interlocutores. Quanto aos demais demonstrativos suprimidos, no original, fazem parte dos grupos nominais suplementados por elementos que facilitam a identificação do objeto de fala, o que torna supérflua a determinação adicional. Como resultado, gęsty szum silnika perde este toque pessoal presente no original e torna-se

${ }^{11}$ Você já ouviu falar sobre esta ilha Breton 100\% autossuficiente? (Facebook do Sr. Mondialisation, 9 de outubro de 2017)

Você já ouviu falar sobre este novo subinspetor? supostamente ele deve vir até nós como chefe do departamento. (Zajas, do abismo, 2015).

12 Você se lembra daquela primeira partida? Nós fizemos isso juntos [...] 0 motor fez esse barulho denso que existe sozinho e atrás do qual a paisagem passa silenciosamente como um filme. E esse frio, porque estávamos voando alto: essas cidades tomadas pelo gelo. (CS, p. 18)

Você se lembra da nossa primeira viagem? Nós estávamos juntos então [...] parecia não haver nada além de um ruído denso do motor, e sob ele a paisagem se movia silenciosamente como um filme. E essa frieza - porque voamos alto: cidades coaguladas em gelo. (PP, p. 32) 


\section{Penista Letras Paras}

ISSN: 2317-2347 - V. 9, n. 1 (2020)

Todo o conteúdo da RLR está licenciado sob Creative Commons Atribuição 4.0 Internacional

generalizável, tanto para todos os voos feitos em conjunto, quanto individualmente. A lembrança é ativada com o sintagma ten chłód. Na sentença em que ele aparece, a lembrança da relação lógica de causa contribui para caracterizar o referente de ce froid no sentido de que mobiliza 0 conhecimento geral sobre a queda de temperatura relacionada à subida em alta altitude. Uma vez transposto para um mundo que pertence ao passado do emissor, o leitor não terá necessariamente a impressão de abandoná-lo, se der uma particular importância à memória das temperaturas extremas, considerando em seguida miasta zakrzepłe w lodzie - estas cidades tomadas no gelo - como uma ilustração metafórica do sentimento físico sentido e memorizado e não como uma memória real.

A análise deste exemplo mostra que, mesmo que certas transferências da língua materna não sejam excluídas a priori, elas devem ser reconsideradas em uma perspectiva mais ampla (textual). É também a este aspecto que devemos sensibilizar os futuros usuários profissionais dessas duas línguas.

\section{Conclusão}

A utilidade do ensino de gramática comparativa nos departamentos modernos de idiomas não deve ser demonstrada. Ela é confirmada pela natureza obrigatória dos cursos dedicados a este assunto. Por outro lado, as questões relativas ao conteúdo e a eventuais referências bibliográficas permanecem em aberto.

Primeiramente, tendo em vista que os estudantes fazem um curso paralelo de gramática descritiva da língua francesa (revisitada em vista do progresso da linguística), a abordagem que Ihes será oferecida na gramática contrastiva não pode se desviar muito, nem a nível terminológico, nem ao das classificações propostas. Mas os trabalhos comparativos disponíveis não são muito recentes (o último, cronologicamente publicado, não procura renovar a proposta). Esta abordagem deve ser, ao mesmo tempo, "justaposta" sem muita dificuldade à descrição tradicional da língua polonesa, a única conhecida pelos bacharéis poloneses. Esta é mais uma razão (além das inegáveis vantagens de qualquer trabalho pessoal) para o qual, em nossa prática de ensino responsável por este tipo de curso, encorajamos os estudantes a fazer um trabalho comparativo a partir de gramáticas unilíngues francesas e polonesas. Esperamos que, no futuro, eles possam encontrar as respostas para possíveis perguntas (ou pelo menos para 


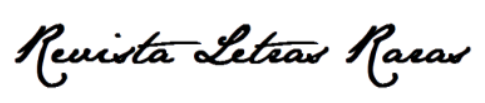

ISSN: 2317-2347 - v. 9, n. 1 (2020)

Todo o conteúdo da RLR está licenciado sob Creative Commons Atribuição 4.0 Internacional

algumas delas, porque também existem problemas que só se destacam em contraste com outro idioma).

Certamente, uma simples comparação de formas e categorias não pode ser satisfatória, mesmo que não seja inútil (de fato, a falha mais frequente em relação ao determinante demonstrativo é a criação de uma forma plural feminina inexistente, cettes, tal qual a flexão polonesa e/ou regularidades polonesas em francês; no curso da morfossintaxe, os estudantes confundem, sistematicamente, os determinantes com os correspondentes pronominais). 0 segundo aspecto, sobre o qual tentamos atrair a atenção dos estudantes, é relativo às diferenças e semelhanças nos empregos das formas disponíveis em ambas as línguas, tanto em nível de construções sintáticas, quanto em nível dos valores semânticos e pragmáticos. Esperamos ter mostrado que, mesmo que duas línguas tenham formas comparáveis, a correspondência entre elas, como habilmente apontou Jonasson (2002, p. 111), não é necessariamente perfeita e seria bom que os estudantes se conscientizassem desse tipo de dificuldade. Como vimos, esse problema não é destacado na literatura disponível. Enquanto se espera por uma gramática comparativa mais eficaz, ou mesmo por um estudo estilístico comparativo, que vise as possíveis dificuldades que possam surgir em todas as etapas de aprendizagem e de trabalho com uma língua estrangeira, pode-se recorrer sempre a trabalhos especializados, comparativos ou tradutológicos (estes últimos estão agora experimentando seu crescimento total e fornecem observações e esclarecimentos interessantes). E é essa trilha que nós privilegiamos, como ilustramos na seção 3.4 .

\section{Referências}

BÜHLER, K. 1934/2009. Théorie du langage. Paris : Agone.

CORBLIN, F. 1987, Indéfini, défini et démonstratif. Genève/Paris : Droz.

DE MULDER, W. 1998. " Du sens des démonstratifs à la construction d'univers ». Langue française, $n^{\circ} 120$, p. 21-32.

DUBOIS, J. et al. 1999. Dictionnaire de linguistique et des sciences du langage. Paris : Larousse.

GARY-PRIEUR, M-N. LEONARD, M. 1998. « Le démonstratif dans les textes et dans la langue ». Langue française, $n^{\circ} 120$, p. 5-20.

GNIADEK, S. 1979. Grammaire contrastive franco-polonaise. Warszawa: PWN.

GREVISSE, M., GOOSSE, A. 2016. Le bon usage. Grammaire française. 16e éd. Bruxelles : De Boeck/Duculot. 


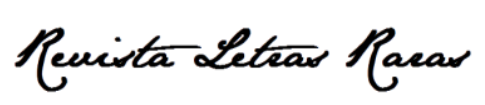

ISSN: 2317-2347 - v. 9 , n. 1 (2020)

Todo o conteúdo da RLR está licenciado sob Creative Commons Atribuição 4.0 Internacional

JAZOWY-JARMUL, M. 2014. "Czy gramatyka kontrastywna jest potrzebna tłumaczowi? ». inTRAlinea. online translation journal, $\mathrm{n}^{\circ}$ spécial, Challenges in Translation Pedagogy.

JODLOWSKI, S. 1973. Ogólnojęzykoznawcza charakterystyka zaimka. Warszawa : PWN.

JONASSON, K. 2002. Références déictiques dans un texte narratif. Comparaison entre le français et le suédois. In : Référence discursive dans les langues romanes et slaves. Lublin : UMCS.

KIELSKI, B. 1957. La structure des langues française et polonaise étudiées à la lumière de l'analyse comparative. Łódź : SSLŁ.

KIELSKI, B. 1959. Słownik terminologii gramatycznej francuskiej i polskiej. Wrocław : Ossolineum.

Kielski, B. 1960. Struktura języków francuskiego i polskiego w świetle analizy porównawczej. Cz. 2, Z zagadnień nauki o zdaniu. Wrocław : Ossolineum.

KLEIBER, G. 1983. « Les démonstratifs (dé)montrent-ils ? Sur le sens référentiel des adjectifs et pronoms démonstratifs ». Le français moderne, $n^{\circ}$ 51(2), p. 99-117.

KLEIBER, G. 1990. « Sur l'anaphore associative : article défini et adjectif démonstratif ». Rivista di Linguistica, $n^{\circ} 2(1)$, p. 155-175.

KLEIBER, G. 2003, « Adjectifs démonstratifs et point de vue ». Cahiers de praxématique, $n^{\circ} 41$, p. 33-54.

KOCZERHAN, M. 2009. Podstawy językoznawstwa konfrontatywnego. Opole : Nowik.

KRÓL-MARKEFKA, A. 2008. " Some structural considerations on the use of contrastive data in teaching English articles ». Studia lagellonicae Cracoviensis, n 125, p. 103-112.

KWAPISZ-OSADNIK, K. 2007. Podstawowe wiadomości z gramatyki polskiej i francuskiej: szkic porównawczy. Katowice : Wyd. UŚ.

LASKOWSKI, R. 1999. Zagadnienia ogólne morfologii. In : Gramatyka współczesnego języka polskiego. Warszawa: PWN.

NEMSER, W. 1975. Problems and prospects in contrastive linguistics. In : Modern linguistic and language teaching. Budapest: Akadémiai Kiadó.

ODAERT, O. 2005. « Saint-Exupéry et son double ». Image [\&] Narrative [e-journal], $n^{\circ} \mathrm{X} / 2$ (25).

PADUCEVA, E. V. 1992. Wypowiedź i jej odniesienie do rzeczywistości. Warszawa : PWN.

PAPIERZ, M. 2003. Zaimki w języku i tekście. Studium słowacko-polskie. Kraków : Universitas.

PISARKOWA, K. 1969. Funkcje składniowe polskich zaimków odmiennych. Wrocław : Ossolineum.

RIEGEL, M., PELLAT, J.-C., RIOUL, R. 2016. Grammaire méthodique du français. 6e éd. Paris : PUF.

SYNOWIEC, H. 2001. Fleksja i nauka o częściach mowy. In : Nauka o języku polskim w zreformowanej szkole. Warszawa : Nowa Era.

SZOBER, S. 1969. Gramatyka języka polskiego. 11e éd. Warszawa : PWN.

TOPOLIŃSKA, Z. 1981. Remarks on the Slavic Noun Phrase. Wrockaw : Ossolineum. 


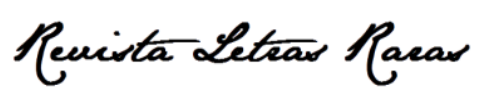

ISSN: 2317-2347 - v. 9, n. 1 (2020)

Todo o conteúdo da RLR está licenciado sob Creative Commons Atribuição 4.0 Internacional

TOPOLIŃSKA, Z. 1984. Składnia grupy imiennej. In : Gramatyka współczesnego języka polskiego. Warszawa : PWN.

WÓJCIK, T. 1974. « Miejsce gramatyki kontrastywnej w procesie nauczania języka obcego ». Studia Rossica Posnaniensia, n 6, p. 159-169.

\section{Textos Literários}

Saint-Exupéry, A. 1953, Courrier Sud. In : OEuvres. Gallimard. [CS]

Saint-Exupéry, A. 1968, Poczta na Południe. Trad. A. Olędzka-Frybesowa. Warszawa : PWN. $[P P]$

\section{Notas}

1. Gniadek (1979, p. 7) aprecia o trabalho de Kielski, mas ressalta a necessidade de "acomodar este confronto", envelhecido, na época, por algumas décadas, "aos progressos da linguística (...) tanto em relação aos métodos, quanto em relação às aquisições concretas da linguística francesa e polonesa".

2. Ver, aqui mesmo, a definição tradicional do pronome. Para uma crítica sobre isso ver, por exemplo, Riegel et al. (2016, p. 358).

3. Os critérios retidos pela gramática tradicional, na definição da classe geral do pronome, são por vezes semânticos (o caráter "não mnêmico", Jodłowski, 1973) e flexionais (caráter variável ou não, tipo de paradigma e declinação) e a classe mesmo muito heterogênea, tanto do ponto de vista semântico, quanto morfológico. As pesquisas centradas sobre os valores referenciais têm mostrado, contudo, que os pronomes formam uma classe léxico-semântica da qual a homogeneidade se justifica pelo papel referencial dos seus representantes (Padučeva, 1992, p. 17).

4. Os nomes, em tais expressões (complementos de tempo ou de maneira) não podem funcionar sem um demonstrativo que "confirma e documenta" o seu caráter definido e com o qual eles formam os grupos fixos.

5. Por questão de justiça, sempre ressaltamos que os autores das gramáticas unilíngues não são muito mais eloquentes sobre esse assunto.

6. 0 que se pode mostrar dessecando os exemplos dados pelo autor. Se o demonstrativo denotando um só homem em Ten pan mnie denerwuje (Ce monsieur m'énerve) nos parece 


\section{Remitta Letras Pacar}

ISSN: 2317-2347 - v. 9, n. 1 (2020)

Todo o conteúdo da RLR está licenciado sob Creative Commons Atribuição 4.0 Internacional

natural sem ser obrigatório, ele o é de outro modo em Daj mi ten ołówek (Donne-moi le [ce] crayon), pronunciado na situação onde entre os interlocutores um só objeto visível corresponde à definição da palavra "crayon". De fato, se nós preferimos Daj mi ołówek, é porque só se pode lustrá-lo por 'le crayon qui est devant/entre nous' (tautologia). Entretanto, a perif'rase que, segundo nós, seria mais apropriada para ten pan, contém mais marcas de ancoragem situacional: 'ce monsieur qui a parlé ou agi de cette façon' e não mais geralmente 'ce monsieur qui est ici avec nous, ce monsieur qui participe à l'acte de communication', como o propõe Topolińska (1981 : 43). Faz-se este tipo de observação "ao vivo" para comentar uma réplica ou um comportamento preciso.

7. Na Bélgica, pode-se dizer normalmente aujourd'hui matin ou aujourd'hui soir. Se a referência ultrapassa o dia que constitui o presente do falante, o polonês recorre ao demonstrativo: Tej niedzieli będę u was (Je viendrai vous voir /ce/ dimanche), onde o demonstrativo indica a distância mais próxima (Pisarkowa, 1969, p. 57). Todavia, uma frase com a determinação zero se interpreta da mesma maneira: $W$ niedzielę będę u was. 